\title{
Soils and Paleosoils of the Galápagos Islands: What We Know and What We Don't Know, A Meta-Analysis ${ }^{1}$
}

\author{
Georges Stoops ${ }^{2}$
}

\begin{abstract}
Accessible information on Galápagos soils is very limited. Much of the existing, although still scarce, information is several decades old and not easily retrieved. The aim of this paper is to present a critical synthesis. Three local soilforming factors (parent material, climate, and vegetation) are briefly highlighted, followed by a more detailed discussion of the hypsometric soil sequence on Santa Cruz, the only island where systematic information was recorded by a Belgian geopedological mission in 1962. Five zones are distinguished from the coast toward the top of the island: a dry coastal area, containing superficial and interstitial reddish, smectite-bearing soils between basalt blocks; a transition zone of brown, also smectite-bearing soils; and three subsequent higher zones covered by deeper, brown soils with probably andosolic characteristics. Trace element analyses point to a uniform composition of the parent material and a more progressed weathering on the higher slopes. Micromorphological characteristics of the soils are discussed. Soils of Santa Fé are comparable with those of the coastal zone of Santa Cruz but show higher amounts of $\mathrm{P}$ and S, probably of avian origin. Deeper, reddish clayey soils cover San Cristóbal and are at least partly preHolocene. On the younger islands, no soils seem to be present.
\end{abstract}

INFORMATION ON the soils of the Galápagos Islands is very scarce, and only a paper by Laruelle in 1966 seems to be known, as explicitly stated by Simkin (1984) and Sabau (2008). In reality more information was published, but it remains practically unknown in the scientific literature and is mostly not retrieved by Internet search tools.

The first scientific information on the soils of the Galápagos was gathered by the Belgian geopedological mission in 1962, organized by Ghent University. This mission, consisting of three scientists (J. Laruelle, P. De Paepe, and G. Stoops), made a systematic survey of the soil cover of the windward slopes of Santa Cruz Island and a part of Santa Fé

\footnotetext{
${ }^{1}$ Manuscript accepted 23 April 2013.

${ }^{2}$ Department of Geology and Soil Science, WE13, Universiteit Gent, Krijgslaan 281, S8, B-000 Gent, Belgium (e-mail: georges.stoops@UGent.be).
}

Pacific Science (2014), vol. 68, no. 1:1-17

doi:10.2984/68.1.1

(C) 2014 by University of Hawai'i Press

All rights reserved
Island and sampled geological outcrops on several other islands (for more details about the expedition see Stoops and De Paepe in press). Based on the fieldwork and preliminary analytical results, Laruelle $(1963,1966)$ proposed a hypsometric distribution of soil types on the southern, southwestern, and southeastern slopes of Santa Cruz and later (1967) presented this in more detail, adding a rough sketch of the spatial distribution. These data were used in the soil map of Ecuador and the FAO World Map. More detailed analyses of the samples collected during the Belgian mission (Laruelle and Stoops 1967, Stoops 1972, 2013, Eswaran et al. 1973, Morrás 1974, 1975, 1976, 1977, 1978, Rodriguez Flores et al. 2006) gave better insight into the characteristics and genesis of these soils. Apart from this, only a hydrodynamic study on some samples from Santa Cruz and San Cristóbal by Adelinet et al. (2008) and a short geomorphological paper by Franz (1980) have contributed to our knowledge of the soils and paleosoils of the archipelago.

The aim of this paper is to present a synthesis of all available information on the soils of the Galápagos. A critical study of the report 
of Laruelle (1966) and other papers mentioned here, supplemented by new microscopic analyses of the samples collected in 1962 (Stoops 2013) allows a better understanding of soil genesis and paleoevironment on Santa Cruz and, by interpolation, the other islands of the archipelago.

\section{MATERIALS AND METHODS}

Because I participated in the only specifically pedological mission to the Galápagos organized to the present and much research has been done in my laboratory, most published papers and additional information were at hand. In addition a systematic literature search using Web of Knowledge, Google Scholar, and Scopus resulted in additional references being identified.

Most reported data were produced in the late 1960s and early 1970s. Analytical methods of that period are often different from those in modern use. A method for determination of allophane content was not yet available, and very little was published about soils on volcanic material, which were not considered as something special in those days. The same is true for the unpublished field descriptions made long before FAO and other guidelines were available. For the micromorphological descriptions the terminology proposed by Stoops (2003) is added in parentheses, where appropriate.

\section{RESULTS}

\section{The Physical Environment}

Parent material, climate, and vegetation are important factors of soil formation and therefore need to be highlighted to understand the distribution and genesis of the soil cover. The Galápagos archipelago is situated on the equator, $1,100 \mathrm{~km}$ west of Ecuador, rising 2,000 to 3,500 $\mathrm{m}$ above the seafloor (Figure 1). The highest point is the top of the volcano Wolf on Isabela Island, reaching $1,707 \mathrm{~m}$ above sea level. In general, the structure of the islands is that of coalescent and/or superposed lava streams in the lower parts and cones of different pyroclastic material in the higher parts, but exceptions occur. According to Banfield et al. (1956) a phase of effusive volcanism was followed by explosive pyroclastic eruptions. Some islands, such as Isabela, are formed of several coalescent volcanoes. The age of the islands increases from west to east due to the Nazca tectonic plate drifting away from the East Pacific Ridge to the southeast over a hotspot. The minimum age of the islands is at least 3.3 million yr (Simkin 1984, Gromme et al. 2010). In historic times, active volcanism has been recorded only on Isabela, Fernandina, Santiago, Pinta, and Marchena (Williams 1966).

The petrology of the Galápagos Islands in general has been studied by McBirney and Ken-ichiro Aoki (1966). They concluded that the lavas are tholeiitic, grading into alkaline basalts. Some islands (e.g., Daphne, Bartolomé) consist dominantly of palagonized hyaloclastites. Others (e.g., Santa Cruz) are covered by younger basaltic lava flows and cinders.

Although the Galápagos Islands are situated on the equator, they do not have a tropical climate because of the influence of interacting ocean currents and winds, governed by the movements of the Inter Tropical Convergence Zone and El Niño events (Alpert 1963, Trueman and d'Ozouville 2010). Climate therefore not only varies between the different islands but is also strongly influenced by altitude. Data on temperature and precipitation are still rather scarce. Before the foundation of the Charles Darwin Research Station (CDRS) only occasional measurements were made during scientific expeditions, apart from systematic measurements during World War II on Baltra airport. Since 1962 the CDRS has systematically recorded climatic data at two locations on Santa Cruz (see Figure 2): at the CDRS station in Puerto Ayora and in Bellavista (www.darwinfoundation.org/datazone/ climate/).

On the higher islands, such as Santa Cruz, a climatic zonation is observed, caused by the stratus cloud layer in the cool season: the dry lowlands gradually change to humid highlands and then to dry uplands. This is the case for the windward side of the islands, whereas the leeward slopes are much drier. The lower 


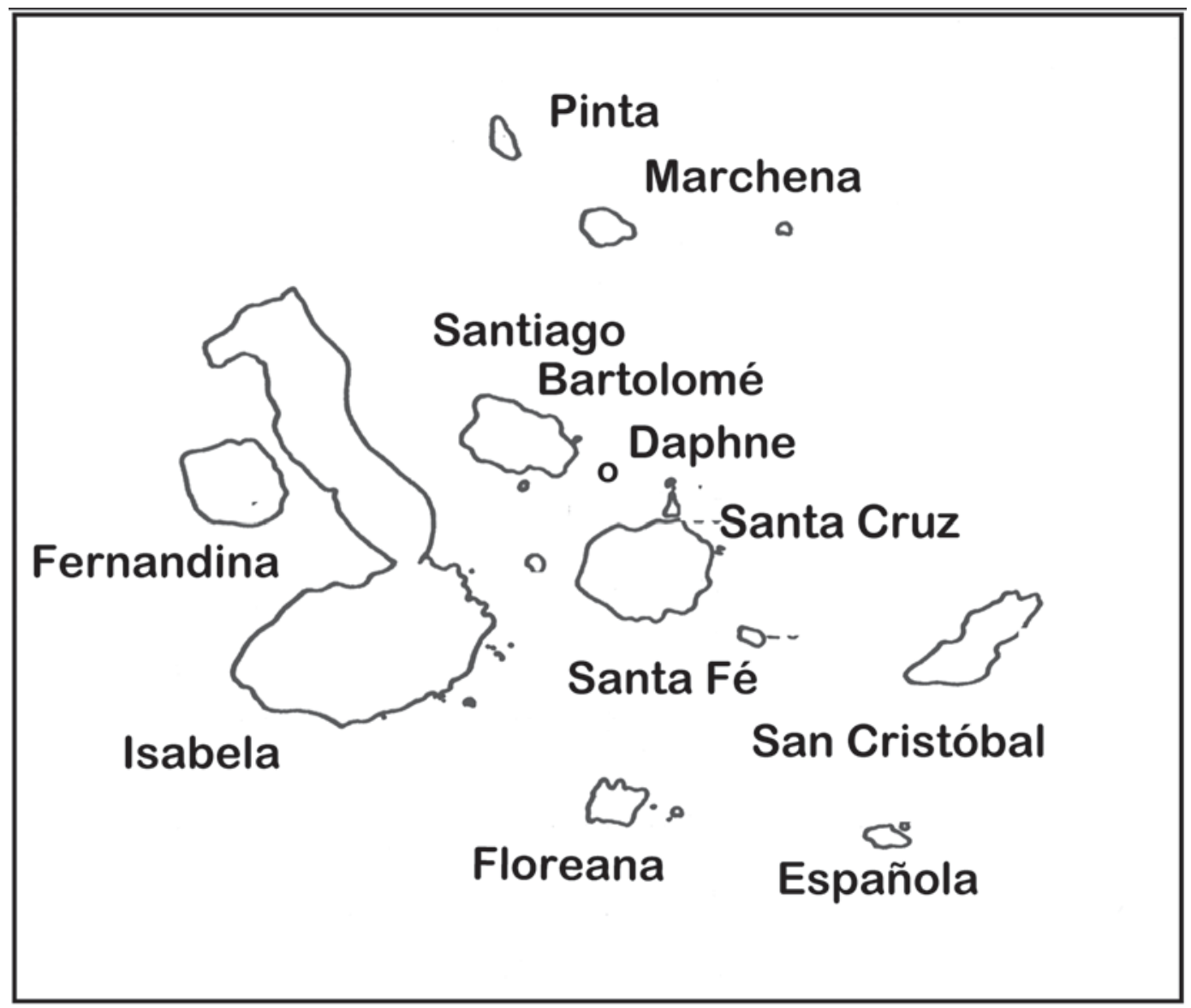

Figure 1. General map of the Galápagos archipelago.

islands have an overall dry climate. During the short warm period $\left(23^{\circ} \mathrm{C}-31^{\circ} \mathrm{C}\right)$ from February to March the coastal areas receive some rain, but this is not the case during the cool season. The lowest temperatures are measured in August and September (around $20^{\circ} \mathrm{C}$ ). Precipitation is very variable, partly as a result of the El Niño effect (see case study of Santa Cruz following). On the windward slopes of the mountains a drizzly rain, called garua, is responsible for continuous humidity throughout the cool season.

Information on paleoclimatic conditions on the Galápagos archipelago is scarce. The most important source of information comes from a paleobotanical study by Colinvaux
(1972), supported by radiocarbon dates, of the sediments of El Junco crater lake on San Cristóbal Island. A reddish clayey sediment more than $10 \mathrm{~m}$ thick fills the lower part of the lake but is interrupted by a gyttja lens of about $0.5 \mathrm{~m}$, too old to be dated by radiocarbon. Gyttja is a subaquatic fine humus form consisting of fine remains of plants and plankton. The clayey sediment is covered by $3.5 \mathrm{~m}$ of gyttja deposit. The bottom of this continuous gyttja deposit has a radiocarbon date of about $10.3 \mathrm{ka}$ and is thus clearly Holocene, provided these old carbon data are correct. The presence of a permanent lake points to a mean precipitation exceeding evaporation. During its existence, periods of deep and shallow lake 


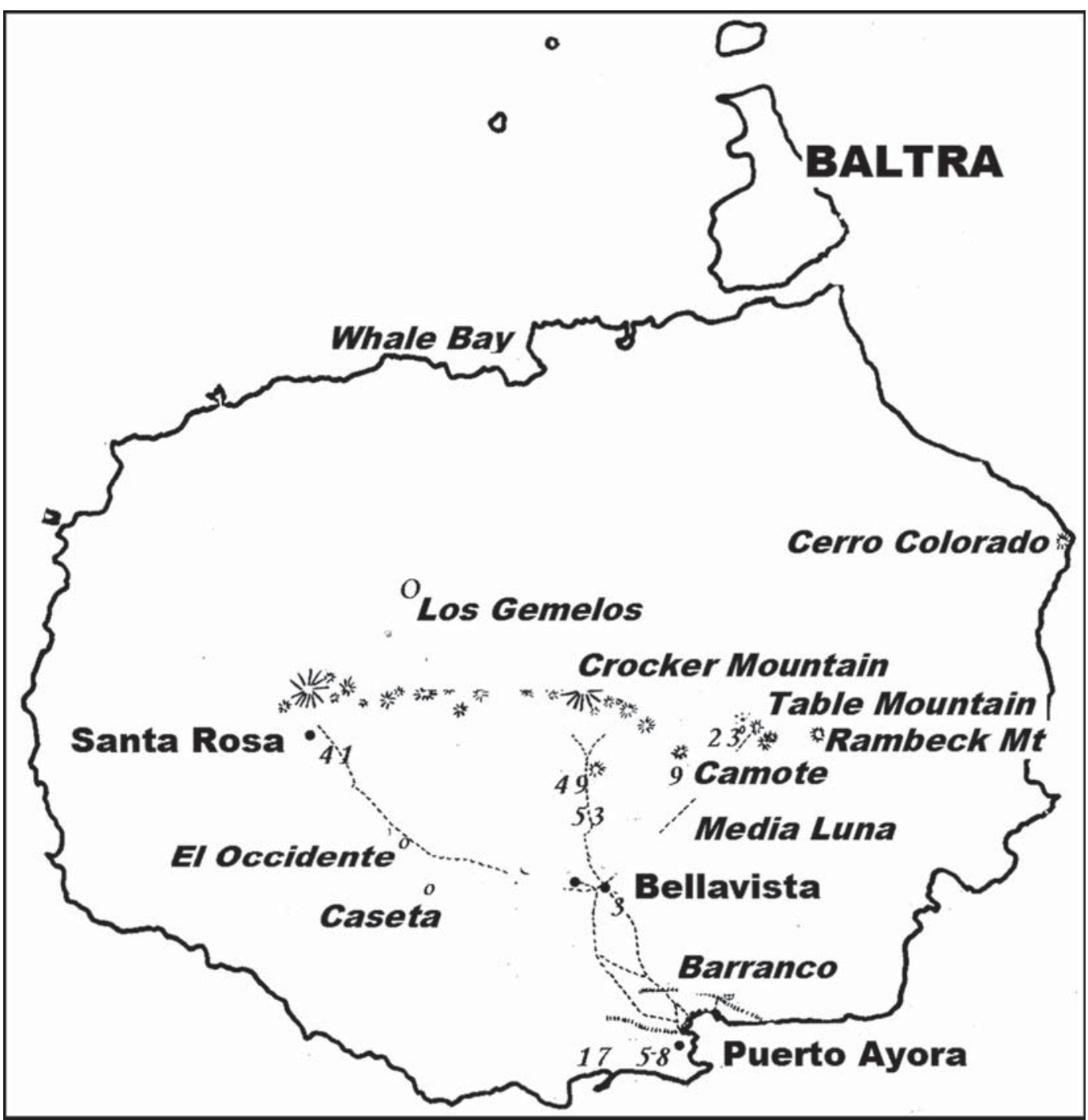

FIgURE 2. Map of Santa Cruz Island (situation in 1962) with localization of profiles discussed. The east-west section through the island is approximately $43 \mathrm{~km}$.

levels alternated, with some fluctuations superposed, as can be deduced from paleobotany. The underlying red, nonlacustrine clays were deposited in a period corresponding to the Würm glaciation (24-10 ka), under drier conditions. The intercalated gyttja lens probably corresponds to a less-dry interglacial period, more than 48 ka (Colinvaux 1972). The occurrence of red colluvial clay points to the erosion of soils formed before the glaciation, when the climate was wetter.

According to Sachs and Ladd (2010) there has been over the last $130 \mathrm{yr}$ a trend toward a wetter mean climate; the driest period of the last 1,200 yr was apparently the end of the nineteenth century, corresponding to the end of the "Little Ice Age" in the Northern Hemisphere. Nevertheless, the current precipitation 
is still lower than in the past, as can be deduced from the relatively high level of the El Junco water level during the last 1,200 yr (Steinitz Kannan et al. 1998). It should be noted that the El Junco crater lake is situated at an altitude of about $450 \mathrm{~m}$, and results are therefore not automatically valid for coastal areas.

Since Darwin's time (1831), vegetation on the Galápagos has been studied by many scientists and from different points of view. With respect to soil studies, plant association patterns are most important. A first practical zonation for the "high islands" was described by Stewart (1911), distinguishing four botanical regions from the coast to the top: (1) dry region, in the coastal area of all islands and including the totally low-elevation islands; (2) transition region, situated between the dry region and the moist region, including the upper part of moderately high islands, such as Marchena, Santa Fé, and Pinzón; (3) moist region, bearing a forest vegetation; (4) grassy region, situated in the upper part of the islands. This zonation is only valid for the windward, thus southern, southwestern and southeastern slopes, not for the leeward northern slopes where the dry region extends to higher altitudes because of the influence of southeast trade winds. A more modern, detailed description of plant communities is given by Hamann (1981). See also Wiggins and Porter (1971).

Information on the soils of the Galápagos, before the Ghent University expedition of 1962, is practically nonexistent. Wolf $(1895 a, b)$ stated that basalt weathering results in thick, blackish-brown soils. Walle (1911) mentioned that in the lower part of the islands the lava is unweathered, whereas in the higher parts it is transformed to shallow, rich soils. According to Stewart (1911) the best substratum is basalt, the poorest pumice. He considered tuff to be good for scrub, not for trees, whereas grass grows best on ash, and cinders are generally bare (presumably because they are less altered, have minimal moisture retention, and are poor rooting material). Franz (1980) suggested that the red soils found on the coastal area of Santa Cruz and other islands are relicts of paleosoils covering vast marine terraces.
Adelinet et al. (2008) mentioned the existence of two unpublished reports on soils of the Galápagos, one dealing with the natural resources of the archipelago (Ingala, Pronareg, ORTSOM, 1989, Inventario cartografico de los recursos naturales geomorfologia, vegetacion, hidricos, ecologicos y biofysicos de las Islas Galápagos, Ecuador), the other with agricultural soils on San Cristóbal (Ipade, Fundar, 2003, Diagnostico fisico y quimico de los suelos agricolas de la Isla San Cristóbal, Galápagos, Ecuador). Both were not accessible to me. Only on Santa Cruz and a small area of Santa Fé were systematic pedological studies made in 1962 by the Ghent University expedition.

\section{Case Study of Santa Cruz Island}

GEOLOGY AND PARENT MATERIAL: TWO distinct bedrock types can be distinguished: the "Platform Series" in the northeastern end and the larger "Shield Series" covering most of the island (Bow 1979 in Geist et al. 2011). The older Platform Series consists of submarine flows with limestone intercalations that contain fossiliferous beds pointing to a probable Pliocene or old Pleistocene age (Dall and Ochsner 1928). K-Ar dates yield an age around 1.3 Ma (Geist et al. 2011). Outcrops of this material are present near Cabo Colorado (Figure 2), in front of the Plaza Islands (see Figure 4), but no soil profiles were studied. The Shield Series, consisting of pāhoehoe and 'àā, yields imprecise K-Ar data ranging between $590 \pm 270 \mathrm{ka}$ and $24 \pm 11 \mathrm{ka}$ (Geist et al. 2011). Cinder and scoria cones are visible in the landscape. A series of approximately east-west oriented fault scarps (the so-called "barrancos") is situated north of Puerto Ayora. In these barrancos, and in several collapse craters, such as Los Gemelos, neither soil formation nor weathering was observed between successive lava flows, indicating that the interval between the eruptions was too short, or the climatic conditions were not suitable for such processes.

According to De Paepe (1968) the lavas of Santa Cruz correspond to tholeiitic and alkaline basalts. Their fabric is almost always porphyric with large plagioclase and $\mathrm{Mg}$-rich 
olivine phenocrysts and abundant interstitial crystals of Ti-augite and small (titano)magnetite and ilmenite grains. Seventeen profiles sampled by the Belgian mission in 1962 were analyzed for major and minor elements by Rodriguez Flores et al. (2006). Correlation and cluster analysis indicated that there are no large differences between parent materials of the different profiles.

Climate: As on all larger islands, the climate of Santa Cruz shows an altimetric zonation from dry at the coast to humid in the mountains. For the period 1965-2011 the mean annual precipitation at the CDRS $(6 \mathrm{~m}$ altitude) was $464 \mathrm{~mm}$ with a minimum of 64 (1985) and a maximum of 2,739 $\mathrm{mm}$ (1983). For Bellavista (315 m altitude) the data are, respectively, $1,089 \mathrm{~mm}, 390.8 \mathrm{~mm}$ (1988), and 2,595 $\mathrm{mm}$ (1997). Houvenaghel (1973) mentioned data for precipitation in 1968 and 1969 for other localities: Caseta $(200 \mathrm{~m})$, $811 \mathrm{~mm}$ and $1,586 \mathrm{~mm}$; Media Luna $(600 \mathrm{~m})$, $1,666 \mathrm{~mm}$ and 2,656 $\mathrm{mm}$. Especially in the coastal area the interannual variability may be enormous (e.g., in May 1983, $660 \mathrm{~mm}$ were recorded, whereas in 1966, 1980, 1984, 1985, 2003, and 2007 no precipitation was measured). Dry periods (with a total of less than 1 $\mathrm{mm}$ precipitation) of more than 80 consecutive days were recorded both in the coastal area and in Bellavista. The maximum daily precipitation measured at the CDRS was $195 \mathrm{~mm}$; in Bellavista it reached $163 \mathrm{~mm}$. Because of its steep slopes and permeable subsurface zones, no permanent streams are found on Santa Cruz, in contrast to San Cristóbal where more than 30 streams exist.

vegetation: For soil scientists, the most practical altitudinal zonation of vegetation for Santa Cruz was established by Bowman (1963) as a tool for describing the environment of different Darwin finches. He distinguished six zones on the windward southwestern, southern, and southeastern slopes ranging from xerophytic in the coastal zone to forest covered by brow epiphytes on the middle of the slopes to a treeless pampa on the highest parts.

The leeward northern slope is much drier and its vegetation corresponds to that of the coastal area and the transition zone. Based on a detailed survey of 33 sample sites, Hamann (1981) recognized more types (subformations) of plant communities along the altitudinal gradient on Santa Cruz.

soils: The Ghent University geopedological expedition in 1962 studied soils in the neighborhood of Puerto Ayora and along trails to Bellavista, El Occidente and Santa Rosa, Crocker Mountain, Camote and near Rambeck Mountain, and Table Mountain (Figure 2). Based on field observations (hundreds of auger observations, 58 profiles) and a few basic analytical data, Laruelle (1966) distinguished five soil belts on the windward side of the island between the coast and $500 \mathrm{~m}$ altitude, partly coinciding with Bowman's (1963) vegetation belts. In 1967 Laruelle published in a monograph on the archipelago a more detailed discussion on the soil morphology and a schematic map of the soil distribution (Figures 3 and 4). Because this paper was published in Dutch, its content did not get the attention it merited. The following paragraphs are based mainly on Laruelle (1966 and 1967) for the field data, Laruelle and Stoops (1967) for minor element analyses, Stoops (1972) for micromorphological descriptions and Eswaran et al. (1973) for chemical and mineralogical data, unless otherwise indicated.

First Soil Zone: In this zone, situated between the coast and 100 to $120 \mathrm{~m}$ altitude, Laruelle (1967) recognized two types of soils: shallow $(<15 \mathrm{~cm})$ red "lithosols" interstitial between basalt lava blocks or on their surface (Table 1, Profile 58), and deeper $(<80 \mathrm{~cm})$ interstitial clayey red soils (Table 1 , Profile 17) occurring as patches, maximum a few tens of square meters (Figure 5). They were considered by Laruelle (1967) as remains of truncated "latosolic" soils. If in the shallow profiles an admixture of pyroclastic material dominates, "regosols" form. The $\mathrm{pH}_{\mathrm{H} 2 \mathrm{O}}$ of the soils ranged between 7.0 and 8.5 , the $\mathrm{pH}_{\mathrm{NaF}}$ between 9.8 and 11 , and the base saturation between $90 \%$ and $100 \%$. The clay content in the shallow soils was rather low (15\%), whereas it exceeded $50 \%$ in the deeper soils. The clay fraction consisted mainly of halloysite and smectite, and $\mathrm{NaOH}$ extractable amorphous material totaled $35 \%$ to $40 \%$. It 


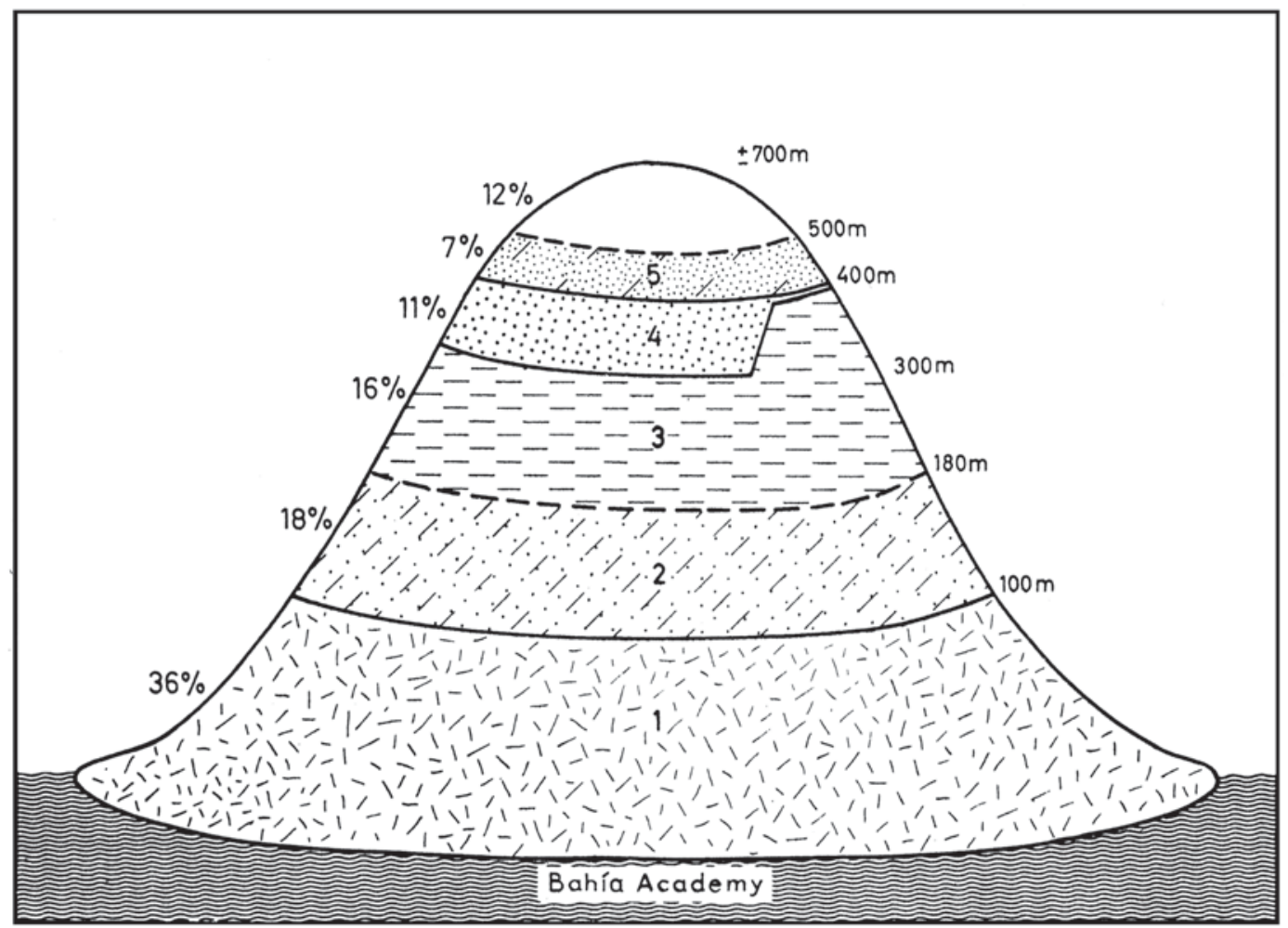

FiguRE 3. Diagrammatic representation of the five pedological zones on the windward slopes of Santa Cruz, with indication of the average area covered by each zone. Altitudes in meters above sea level. (Laruelle 1967).

is, however, well known that this method strongly affects poorly crystalline minerals and therefore is no longer considered as a measure for the allophane content. $\mathrm{Fe}_{2} \mathrm{O}_{3 \mathrm{DCB}}$ (dithionite extractable free iron) ranged between $2.3 \%$ and $10 \%$. Thin-section studies show the presence of fragments of limpid clay coatings, pointing to illuviation processes. Calcite nodules, lenticular gypsum crystals, and whevellite phytolites in plant remains are in agreement with a dry environment. Between crossed polarizers birefringent streaks are visible in the clay mass (well-developed striated b-fabric) in agreement with its smectitic nature and shrink and swell phenomena.

This zone, bearing xerophytic vegetation, corresponds to the "dry region" of Stewart (1911) and to the "arid coastal zone" and part of the "transition zone" of Bowman (1963).

Second Soil Zone: This zone is situated between 100 and $120 \mathrm{~m}$ and about $180 \mathrm{~m}$ alti- tude and gradually merged into the third zone. The lower part of the AC profiles is always developed in basalt weathering products, with the weathering front never occurring below $70 \mathrm{~cm}$ depth (Table 1, Profile 3 ). In the upper part of the profile the influence of pyroclastic materials increased with altitude. The $\mathrm{pH}_{\mathrm{H} 2 \mathrm{O}}$ of these soils ranged between 7.5 in the top horizon to 6.5 in the solum, the $\mathrm{pH}_{\mathrm{NaF}}$ between 9.2 and 9.8 , and the base saturation between $70 \%$ and $85 \%$. The clay fraction contained halloysite and smectite, with a minor amount of feldspars; the total $\mathrm{NaOH}$ extractable amorphous material amounted to $40 \%$. $\mathrm{Fe}_{2} \mathrm{O}_{3 \text { DCB }}$ was about $6 \%$. Micromorphology shows the presence of continuously oriented limpid clay coatings, pointing to illuviation processes, small iron oxide nodules related to short periods of hydromorphism and birefringent streaks (striated b-fabric) in the clay mass, in agreement 


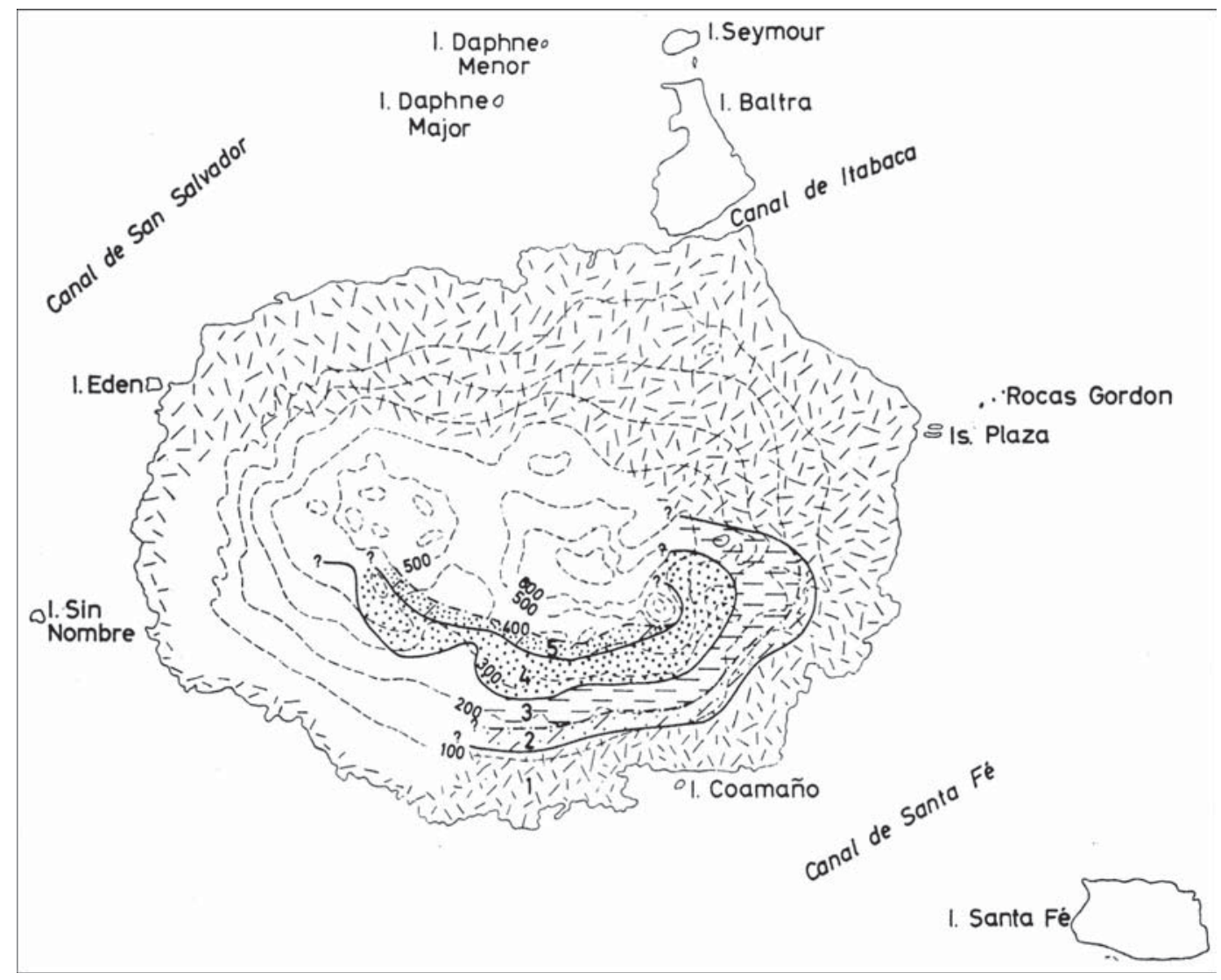

Figure 4. Sketch map of distribution of the five soil zones on Santa Cruz. (Laruelle 1967).

with the presence of smectite. The lower part of the profile clearly shows the characteristics of pedoplasmated material (Stoops and Schaefer 2010). Morrás (1974) described in rock fragments the weathering of plagioclase to gibbsite, through an amorphous phase.

This second zone corresponds to the "transition zone" of Stewart (1911) and is only a part of the "transition zone" of Bowman (1963), corresponding to a dense forest of mesophytic and xerophytic associations.

Third Soil Zone: This zone is situated between about $180 \mathrm{~m}$ and $300 \mathrm{~m}$, locally up to 400 m. Laruelle (1966, 1967) distinguished two soil types: "Brown Forest soils" (sol brun) with $\mathrm{A}(\mathrm{B}) \mathrm{C}$ type profile (Table 1, Profile 9), and "Gray-brown Podzolic soils" (sol brun lessivé) with ABC profile (Table 1, Profile 53), with weakly expressed Bt horizons. The soils have "andosolic" characteristics. Andosols have a bulk density less than 0.85 , a dominance of amorphous material in the clay fraction, or more than $60 \%$ volcanic glass. The basaltic parent material can occur starting from $60 \mathrm{~cm}$ depth but does not occur deeper than $1 \mathrm{~m}$.

Analytical data are almost lacking for this zone. The $\mathrm{pH}_{\mathrm{H} 2 \mathrm{O}}$ ranges between $7.5\left(\mathrm{~A}_{11}\right)$ and $6.5(\mathrm{C})$. Thin-section studies (Stoops 2013) show a mainly fine angular blocky microstructure, a completely isotropic clay mass (undifferentiated b-fabric), and the absence of pedofeatures, corresponding to the microfabric of soils on volcanic ash (Sedov et al. 2010). Stoops (1972) mentioned that soil structure has been changing in some areas as a result of the introduction of soil fauna from the South 
TABLE 1

Field Description of Typical Profiles (Data from Geopedological Mission of Ghent University, 1962)

Profile 17. Coastal plain, north of Puerto Ayora, near barranco. Interstitial between basalt blocks, on a stony plateau covered by xerophytic vegetation (Opuntia) at about $20 \mathrm{~m}$ above sea level (Figure 5)

0-5 cm $\quad \mathrm{A}_{1}$. Blocky structure with granular substructure; coatings along root channels; loamy clay; many small rock fragments; many roots. 2.5 YR 3/4 (dark reddish-brown) (moist), 5 YR 3/3-3/4 (dark reddish-brown) (dry)

$5-80 \mathrm{~cm} \quad \mathrm{C}_{1}$. Coarse angular blocky structure, sometimes somewhat platy, covered by clay coatings; clayey; many small rock fragments; many roots until $40 \mathrm{~cm} .2 .5$ YR 3/4-2/4 (dark reddish-brown) (moist), 2.5 YR 3/6 (dark red) (dry)

$80-\downarrow \mathrm{cm} \quad \mathrm{C}_{2}$. Parent rock, not or partly weathered

Profile 58. Superficial soil on and interstitial between numerous basalt blocks in the coastal plain west of Puerto Ayora with xerophytic vegetation

0-10/20 cm A $\quad \mathrm{A}_{1}$. Loose granular structure, moderately firm. 5 YR 5/6 (yellowish-red), locally 5 YR 3/2 (dark reddish-brown)

Profile 3 . Brown soil on weak slope (maximum $3^{\circ}$ ) at the entrance of Bellavista, at an altitude of about $155 \mathrm{~m}$ 0-10 cm $\quad A_{11}$. Humiferous; crumb structure; no or very few coatings; loamy; 10 YR 2/2 (very dark brown)

$10-25 \mathrm{~cm} \quad \mathrm{~A}_{12}$. With humus infiltration and clear clay enrichment; coarse crumb structure; few clay coatings; loamy; 7.5 YR 3/2 (dark brown)

$25-55 \mathrm{~cm} \quad \mathrm{C}_{(\mathrm{g})}$. In situ weathering clay; weakly expressed gley phenomena; compact; many clay coatings; clayey; 5 YR 3/3-3/4 (dark reddish-brown)

$55-\downarrow 70 \mathrm{~cm}$ Weathering basaltic rock; 5 YR 4/2-4/3 (dark reddish-gray to reddish-brown) (weathered rock) and 2.5 YR 6/2 (pale red) (weathering rock)

Profile 23. Plateau near Table Mountain, characterized by an alternation of small basins and ridges, similar to gilgai. The profile is on one of the small ridges covered with grass in the open forest, at about $365 \mathrm{~m}$ altitude (Figure 6)

0-3 cm $\quad \mathrm{A}_{01}$. Humiferous; very coarse blocky structure; loamy, abrupt boundary; 10 YR 3/2 (very dark gray brown)

3-20 cm A A $\quad$ A Humiferous; weak columnar structure; clayey loam; no clay coatings; roots; 10 YR 4/2

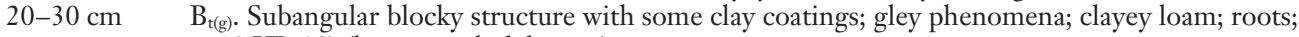
10 YR 4/3 (brown to dark brown)

30-40 cm $\quad \mathrm{C}_{1 \mathrm{~g}}$. Weathering material, weak subangular blocky structure; clayey loam; gley mottles; no roots;

$40-\downarrow \mathrm{cm}$ C. 10 YR 4/3-5/3 (brown to dark brown) (pale zone), 5 YR 5/6 (yellowish-red) (rusty patches)

Profile 53. Shallow depression in vast plain sloping about $3^{\circ}$, along the trail from Bellavista to the Pozos, at an elevation of about $240 \mathrm{~m}$, covered with bamboo cane

0-7 cm $\quad \mathrm{A}_{11}$. Humiferous; crumb to angular blocky structure; loamy clay; roots; 10 YR 3/2 (dark to very dark gray brown)

7-21 cm $\quad \mathrm{A}_{12}$. With humus infiltration; crumb to angular blocky structure or more compact; loamy clay; roots; 10 YR $3 / 2$ (dark to very dark gray brown)

21-110 cm B. Weakly clayey horizon; more compact; roots; few, weakly weathered rock fragments between 60 and $80 \mathrm{~cm}$, many below $80 \mathrm{~cm} ; 10$ YR 3/2-3/3 (very dark gray brown to dark brown)

$110-\downarrow \mathrm{cm} \quad$ Only slightly weathered vesicular basalt

Profile 9. At the foot of the Camote cone, where the steep slope $\left(12-15^{\circ}\right)$ starts, along the trail to the higher plain (pampa intramontana), at about $470 \mathrm{~m}$ altitude

0-5 cm $\quad \mathrm{A}_{1}$. Humiferous; crumb to granular structure; powdery; clayey; few roots; 7.5 YR 3/2 (dark brown)

$5-32 \mathrm{~cm} \quad \mathrm{~B}_{1}$. Granular structure, powdery, slightly clayey, few roots, 10 YR 3/4 (dark yellowish-brown)

32-70 cm $\quad \mathrm{B}_{2}$. Granular, powdery; more clayey; few roots; 10 YR 3/4-4/4 (dark yellowish-brown)

$70-\downarrow 106 \mathrm{~cm} \quad$ C. Weakly developed granular, locally more compact; more clayey; interstitial between rock fragments; 10 YR 3/4-4/4 (dark yellowish-brown) 
TABLE 1 (continued)
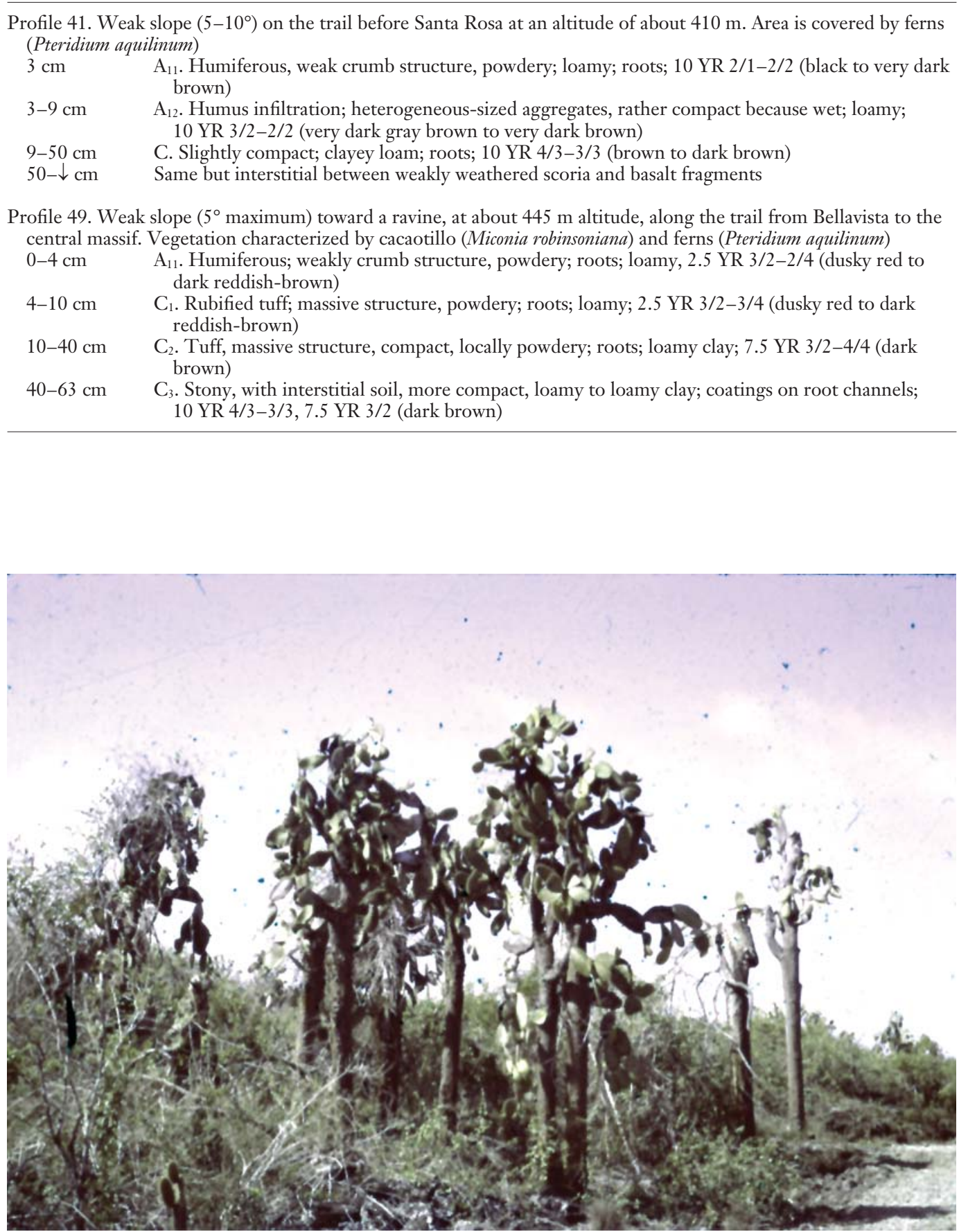

FIgURE 5. Xerophytic vegetation consisting of Opuntia echios and scrub in the coastal zone. Soils occur interstitially between lava blocks. (Photograph by G. Stoops, June 1962.) 
American mainland, disturbing the equilibrium reached by the endemic species. Kastendalen (1982) described how the endemic, 1-inch-long $(2.54 \mathrm{~cm})$ earthworm has been gradually replaced by a 4-inch-long $(10.16 \mathrm{~cm})$ species in the Scalesia forest. Originally soil structure was loose and powdery; after the introduction of the mainland species the topsoil turned into mud in the rainy season, becoming hard when the soil dried, and finally breaking up in clods. A stable granular microstructure is finally formed after rain.

Within the third zone, a group of azonal profiles occurs, not mentioned by Laruelle (1966, 1967). They are situated near Table Mountain in flat depressions with a gilgai-like microtopography (Table 1, Profile 23) (Figure 6). Gilgai is a hummocky microtopography with an alternation of microdepressions and microheights, usually a few centimeters or decimeters in height, on clayey soils sub- ject to shrink and swell. The $\mathrm{pH}_{\mathrm{H} 2 \mathrm{O}}$ ranges between $5.8\left(\mathrm{~A}_{11}\right)$ and $5.5(\mathrm{Cg})$, the $\mathrm{pH}_{\mathrm{NaF}}$ between 8.8 and 9.6 , and the base saturation between $58.5 \%\left(\mathrm{~A}_{11}\right)$ and $16.5 \%(\mathrm{Cg})$. The clay fraction consists of smectite and halloysite and about $40 \% \mathrm{NaOH}$ extractable amorphous material. $\mathrm{Fe}_{2} \mathrm{O}_{3 \text { DCB }}$ ranges between $6.5 \%$ and $8 \%$. Micromorphological studies show the presence of many pale yellow limpid fine clay coatings, sometimes covered by thin colorless isotropic coatings, and many birefringent streaks (well-developed striated b-fabric) in the clay mass, in agreement with the smectitic nature of the clay fraction.

This zone, dominated by Scalesia pedunculata forest, corresponds to the lowest part of Stewart's (1911) "moist region" and Bowman's (1963) "Scalesia forest" zone. When the basalt is situated at more than $1 \mathrm{~m}$ depth, the Scalesia forest disappears. The origin of the gilgai-like microtopography is not clear. It

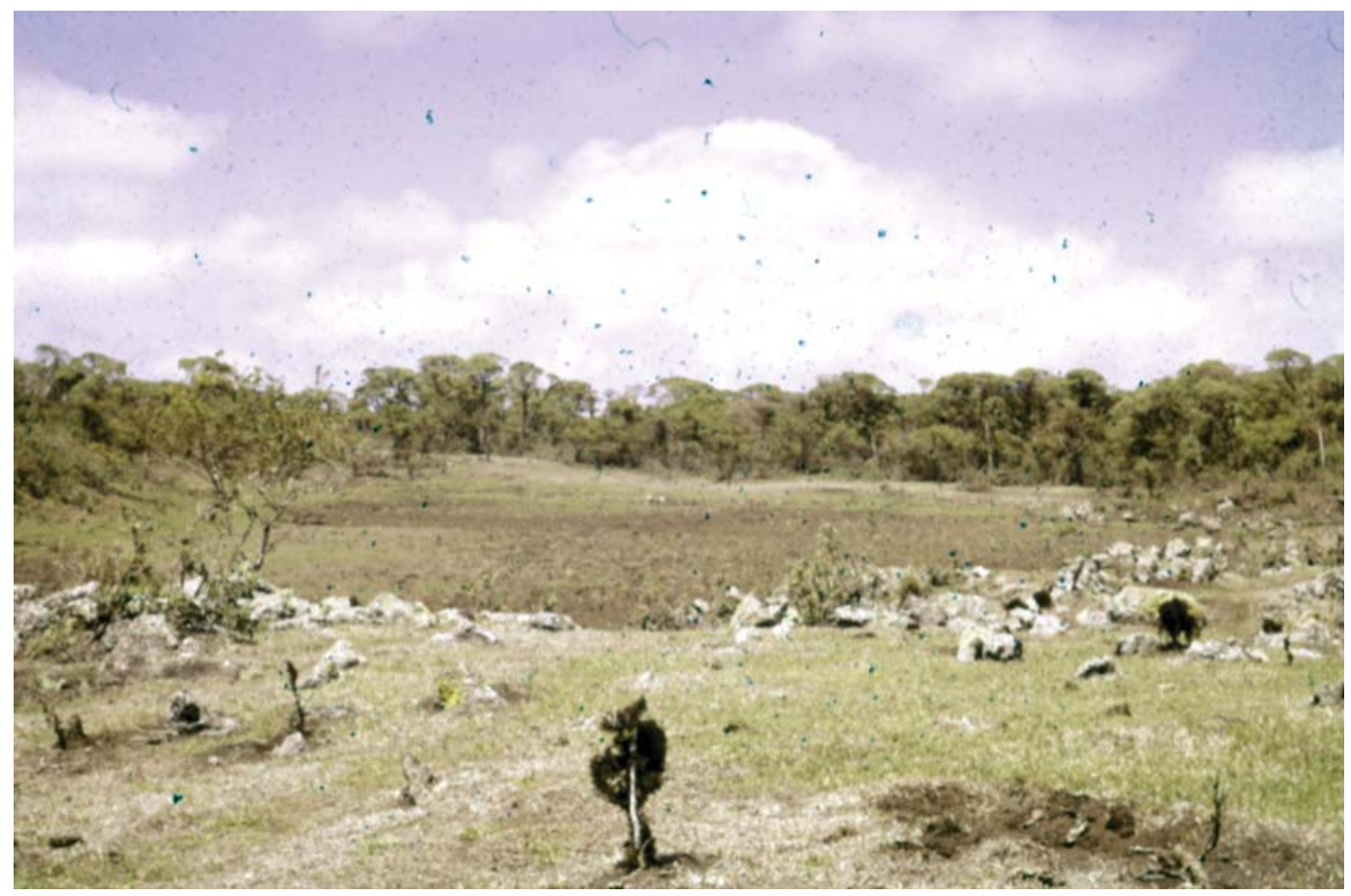

Figure 6. Depression near Table Mountain in the Third Soil Zone with gilgai-like microrelief. (Photograph by G. Stoops, August 1962.) 
might be the result of biological activity, more specifically of the Galápagos tortoises using these ponds in the wet season (Stoops 1972).

Fourth Soil Zone: Situated above the third zone, it extends up to about $400 \mathrm{~m}$. It is characterized by deep brown or reddish-brown soils formed in pyroclastic material, without basaltic substrate in depth (Table 1, Profile 9). Laruelle (1967) classified these soils, with AC profiles and often visible stratification, as "andosols." The $\mathrm{H}_{\mathrm{H} 2 \mathrm{O}}$ is about 6.0 , and the $\mathrm{pH}_{\mathrm{NaF}}$ ranges between 10.5 and 11.5 , pointing to substantial amounts of amorphous material (U.S. Department of Agriculture 1967). The base saturation is low, ranging between $32.7 \%$ (A11) and $11.4 \%$ (C). The clay fraction consists of halloysite and gibbsite and between $3 \%$ and $50 \% \mathrm{NaOH}$ extractable amorphous material. $\mathrm{Fe}_{2} \mathrm{O}_{3 \text { DCB }}$ ranges between $13 \%$ and $16 \%$. It is interesting that Adelinet et al. (2008) mentioned kaolinite, gibbsite, and hematite as components of the clay fraction, whereas Eswaran et al. (1973) mentioned halloysite and gibbsite, locally endelite (metahalloysite). The presence of halloysite is more in agreement with the optical isotropic aspect of the clay mass (undifferentiated b-fabric) in thin sections. Micromorphology shows a blocky or granular microstructure, absence of pedofeatures, and an isotropic clay mass (undifferentiated b-fabric), typical for andosols on volcanic ash (Sedov et al. 2010). In the case of a granular microstructure, the granules commonly have a concentric fabric, sometimes even with a mineral nucleus.

This zone corresponds to part of the "moist region" of Stewart (1911) and the "Brown zone" of Bowman (1963), as far as the central north-south section is concerned. In other parts of the island the sequence of soil zones is not always so clear, and the Fourth zone can border the Second zone in the lower part, or the grassy zone, situated above the Fifth zone.

Fifth Soil Zone: It starts at $400 \mathrm{~m}$ and is characterized by soils developed in a mixture of pyroclastic materials and fragmented, fresh or weathered basalt fragments at less than $1 \mathrm{~m}$ depth. Two soil and vegetation types are distinguished: (a) between 400 and 500 m moderately deep brown to reddish-brown soils with no or weak horizon differentiation (comparable with the "andosols" of the Fourth zone) under brushwood composed of Miconia robinsoniana (Table 1, Profile 49); and (b) very shallow, brownish to grayish, partly gleyified soils with a dark A horizon under fern (Pteridium aquilinum) occurring above $500 \mathrm{~m}$ (Table 1 , Profile 41). In this zone basalt lava flows locally occur at the surface. The $\mathrm{pH}_{\mathrm{H} 2 \mathrm{O}}$ is rather low, ranging between 4.7 and 5.5, whereas $\mathrm{pH}_{\mathrm{NaF}}$ is high, ranging between 11.5 and 12.1 with a base saturation of $1.7 \%$ to $0.4 \%$ in the solum. Mineralogical and micromorphological characteristics are similar to those of the soils of the Fourth zone, although the amount of $\mathrm{NaOH}$ extractable amorphous material increases to $65 \%-77 \%$. $\mathrm{Fe}_{2} \mathrm{O}_{3 \text { рсв }}$ ranges between $14 \%$ and $17 \%$ in the solum, and $\mathrm{Al}_{2} \mathrm{O}_{3 \text { DСв }}$ between $7.4 \%$ and $9 \%$, whereas it is generally less than $1 \%$ in the soils of the lower zones.

The Fifth zone corresponds to the upper part of Stewart's (1911) "moist region" and part of his "grassy region," and to a combination of Bowman's (1963) "Miconia belt" and the fern-rich part of his "upland zone."

The upper grassland, with a presumably dryer climate, was not surveyed by the Belgian mission in 1962, and no information is available on those soils. From descriptions of botanists (e.g., Hamann 1981) it seems clear that locally thick peat areas occur; Histosols may thus be expected locally.

SOIL NAMES: Soil names, as present in literature, are summarized in Table 2. It should be noted however that classification has been assessed in all cases, except possibly for Adelinet et al. (2008), based on incomplete field descriptions and without access to the necessary analytical and climatological information and should be treated with caution.

SOIL CHARACTERISTICS IN RELATION TO ALTITUdE: From the preceding information, some general trends can be deduced. Soils of the higher zones are more weathered than those of the First and Second zones: they have a lower $\mathrm{pH}$, a lower base saturation, a higher $\mathrm{Fe}_{2} \mathrm{O}_{3 \text { DCB }}$ value, and do not contain smectite. Laruelle and Stoops (1967), studying some minor elements in nine profiles from Santa Cruz by $\mathrm{X}$-ray fluorescence, stated that $\mathrm{Ti}$, 
TABLE 2

Names Given to Soils of Different Zones Distinguished by Laruelle (1966, 1967)

\begin{tabular}{|c|c|c|c|c|c|}
\hline Reference & $\begin{array}{c}\text { First or Coastal } \\
\text { Zone }\end{array}$ & $\begin{array}{c}\text { Second or } \\
\text { Transition Zone }\end{array}$ & $\begin{array}{c}\text { Third or Scalesia } \\
\text { Zone }\end{array}$ & $\begin{array}{c}\text { Fourth or Brown } \\
\text { Zone }\end{array}$ & $\begin{array}{l}\text { Fifth or Miconia } \\
\text { or Fern Zone }\end{array}$ \\
\hline Laruelle $(1966,1967)$ & $\begin{array}{l}\text { Lithosol, } \\
\text { Regosol }\end{array}$ & $\begin{array}{l}\text { Brown soil with } \\
\text { AC profile }\end{array}$ & $\begin{array}{l}\text { Sol brun or sol } \\
\text { brun lessivé }\end{array}$ & Andosol & Andosol \\
\hline $\begin{array}{l}\text { Laruelle and Stoops } \\
\qquad(1967)^{a}\end{array}$ & $\begin{array}{l}\text { Ustropept, } \\
\text { Haplustult }\end{array}$ & $\begin{array}{l}\text { Haplustoll, } \\
\text { Hapludoll }\end{array}$ & Argiudol & Umbric Vitrandept & $\begin{array}{l}\text { Andic } \\
\text { Troporthent }\end{array}$ \\
\hline Stoops $(1972)^{a}$ & Ustropept & & Ustochrept $^{d}$ & & \\
\hline Eswaran et al. $(1973)^{b}$ & Ustropept & & Hapludult $^{d}$ & Dystrandept & Dystrandept \\
\hline Adelinet $(2008)^{c}$ & & Lithic Argiudoll & $\begin{array}{l}\text { Lithic Argiudoll, } \\
\text { Agiudoll }^{d}\end{array}$ & $\begin{array}{l}\text { Lithic Dystrandept, } \\
\text { Lithic Argiudoll }\end{array}$ & \\
\hline
\end{tabular}

${ }^{a}$ U.S. Department of Agriculture (1960).

${ }^{b}$ U.S. Department of Agriculture (1967).

'Soil zones and classification system used not specified in the paper.

${ }^{d}$ Atypical profile in depression.

$\mathrm{Mn}, \mathrm{Ni}$, and $\mathrm{Ba}$ are more abundant in the soils of the Third zone on, compared with those of the First and Second zones. Compared with the parent material (De Paepe and Stoops 1969) their Ni (102 ppm rock, 130 ppm soil), $\mathrm{Cu}$ (25 ppm rock, 57 ppm soil) and especially $\mathrm{Zr}$ (161 ppm rock, $262 \mathrm{ppm}$ soil) content is higher, but their Sr content (379 ppm rock, $108 \mathrm{ppm}$ soil) much lower. Analysis of the principal components of 17 profiles sampled by the Belgian mission in 1962 (Rodriguez Flores et al. 2006) showed a decrease of Si and an increase of immobile elements with altitude, thus an increase in weathering. Moreover the analysis showed that horizon differentiation is more pronounced in the higher parts than in the lower parts. Adelinet et al. (2008), studying the hydraulic conductivity of a series of soils on Santa Cruz (five samples) and San Cristóbal (seven samples), found a range of $1.5 \times 10^{-3}$ to $1.7 \times 10^{-6} \mathrm{msec}^{-1}$. Both hydraulic conductivity and porosity decreased systematically with altitude.

SOIL DISTRIBUTION AND GENESIS: In his papers, Laruelle (1963, 1966, 1967) considered only soils on slopes to develop his hypsometric zonality of soils on Santa Cruz. Azonal soils, such as those in depressions, were not discussed. His ideas were much influenced by the (then just published) vegetation zones of Bowman (1963) and the hypothesis that the island consists of a superposition of lava streams covered by younger volcanic ash on the higher slopes. The distribution of the red soils on the leeward side of the island (Figure 2 ) is a guess, not confirmed by field studies, and therefore may be excluded.

The deep red soils in the coastal area are considered to be remains of truncated latosols. This is most probably not the case; they rather resemble Terra Rossa soils (these are reddish, sesquioxide rich, only partly weathered soils formed in regions with contrasting climatic conditions; they are often paleosoils but still actively form in some regions), as found in Mediterranean areas, and the absence of saprolite suggests a colluvial material on marine plateaus, as suggested by Franz (1980) and Stoops (2013). Regosols in the coastal area are, according to Laruelle, caused by local colluvial material with an admixture of pyroclastic material. Stoops (2013) observed only exceptional small glass fragments in these materials, probably derived from airborne ash of other islands. There are no objective indications to consider these red soils as paleosoils. The hypothesis is based on color only but is contradicted by the fact that they are less weathered than soils on higher slopes. The presence of long dry periods in the coastal area, and the continuously moist conditions on the slopes, may explain the difference in color, as the rubification process takes place only in alternating moist and dry conditions. Grant (1981), studying tree rings on Santa Cruz, concluded that already in the 
transition zone trees are less often water stressed than in the coastal area. Whitish soils were sampled in the dry coastal zone by Laruelle in 1964, both on and below the barranco, but not considered in his zonations. The andosolic properties of the soils in the Third through Fifth zones are not confirmed by physicochemical data. Their micromorphological properties do not always correspond to those of real Andosols as described by Stoops (2007) and Sedov et al. (2010).

A systematic micromorphological study of all 68 profiles sampled in 1962 suggests that the hypsometric zonation of the Third through Fifth zones is not that evident. This can be deduced also from Laruelle's (1967) ambivalent description of the Fourth zone mentioned earlier. No volcanic glass was found (Stoops 2013), which seems logical in view of the relatively old age of the island. Further studies on representative profiles of all zones collected in 1962 in progress at the Ghent University in the Laboratory of Soil Science (Director Prof. Dr. E. Van Ranst) will provide more information on these issues.

Large parts of the island remain unexplored with regard to soils: the drier upper grasslands, with inclusions of Histosols; the leeward side; and the region where the "Platform Series" form the parent rock. Saline soils near the coast and mangrove soil also remain unexplored. A study of the soils and sediments inside collapse craters (e.g., Los Gemelos) could yield more information on climatic changes because xerophytic vegetation occurs there, although they are situated in moist regions.

To date there is no proof of a polygenetic origin of the soils of Santa Cruz, except for the coastal soils, probably formed in colluvial soil sediments. This seems difficult to understand for an island 590 $\pm 270-24 \pm 11$ thousand yr old (Geist et al. 2011), taking also into account the substantial climatic and sea level changes during the Pleistocene, but one should bear in mind that the surface deposits (scoria, ash) in which the soils develop are younger than the basalts. It indicates that no drastic climatological changes have taken place since pedogenesis started.

\section{Soils of Other Islands}

During the 1962 geopedological mission some of the islands younger than Santa Cruz were visited only briefly, such as Bartolomé, Santiago, and Daphne, and no developed soils were detected. Nothing has been published on the soils of the larger, active volcanic islands, but it is unlikely that pedogenesis has taken place, considering their young age. On the older islands (e.g., Santa Fé, San Cristóbal, and Floreana), however, there is a better chance of finding soils.

\section{Santa Fé}

According to Simkin (1984), Santa Fé is between 2.6 and 2.8 million yr old, compared with $590 \pm 270 \mathrm{Ka}-24 \pm 11 \mathrm{Ka}$ for the Shield Series of Santa Cruz. The petrology and the vegetation of the coastal area are comparable with those of Santa Cruz. No meteorological data are available. During the Belgian geopedological mission of 1962 the coastal area was investigated and some analyses were published later (Laruelle and Stoops 1967, Morrás 1975, 1977, 1978). Profiles were sampled at four locations ranging between $90 \mathrm{~m}$ (tableland on Horst II) and $10 \mathrm{~m}$ (basin of Graben I) altitude. Soils at 70 and $90 \mathrm{~m}$ altitude were classified as Ustropepts, and those in the lower parts as Haplustalfs and Rhodustalfs (U.S. Department of Agriculture 1960). Morrás (1975, 1977) described clay orientations in the clay (striated bfabrics), probably pointing to smectitic clays, but no clay coatings were described. It is however not excluded that due to swelling and shrinking, caused by alternating wet and dry conditions, former clay coatings are incorporated in the micromass. Yellowish, isotropic nodules in these soils were analyzed by Morrás (1978). X-ray diffraction analysis points to a poorly crystalline calcium phosphate, probably of animal origin (guano). No information is available on the soils of the higher slopes. It would be interesting to know whether the reddish soils extend to those higher areas, as they do on San Cristóbal. 


\section{San Cristóbal}

This island is older than Santa Cruz and therefore weathering and soil formation should be much more advanced. Red soils seem to cover even the higher slopes, as mentioned by Franz (1980) and as can be deduced from the fact that erosion products of red soils occur at the bottom of El Junco crater lake at $450 \mathrm{~m}$ altitude (Colinvaux 1972). Adelinet et al. (2008) studied the hydraulic conductivity and clay mineralogy of a series of seven samples. The clay fraction of the soils at the lowest elevations is characterized by kaolinite and gibbsite; at higher elevations the clay fraction is characterized by gibbsite and kaolinite. In deeper parts of the profiles smectite occurs. The soils are classified as Vertic Haplustalfs, except the highest located profile, which is considered a Rhodudalf.

It is thought that Floreana also bears a soil cover, but no information is available.

\section{DISCUSSION AND CONCLUSIONS}

Although our knowledge of Galápagos soils is greater than supposed (Sabau 2008), it is still very limited. Only for the soils of Santa Cruz do we have systematic information, but even there we do not have details for all landscape units of the island, and the analytical results were derived using mostly outdated methods. It is strange that so little information is available (only six isolated samples) on the soils of San Cristóbal, the island with the longest agricultural history (e.g., the ill-famed sugarcane plantation El Progresso founded in 1832). On Floreana, also populated since 1870 , no data exist at all. Knowledge of the soils of the Galápagos is not only of scientific interest but also of ecological and economic importance.

A better understanding of the genesis of soils and paleosoils on the Galápagos could help us in understanding past climates. For instance the reddish soils on Santa Cruz are restricted to the dry coastal areas and totally absent on the higher, always moist slopes, and therefore are considered a result of ongoing rubification. If they are comparable with the soils of San Cristóbal, it means that in the past, before the Holocene (see discussion on paleoclimates), a similar Mediterranean-type climate was present over the whole island, much different from the current situation. It is however also possible that the red soils on San Cristóbal are more weathered than those on Santa Cruz and have to be compared with more weathered red tropical soils. Many of these questions will remain until more information becomes available on the soils of the Galápagos.

\section{Literature Cited}

Adelinet, M., J. Fortin, N. d'Ozouville, and S. Violette. 2008. The relationship between hydrodynamic properties and weathering of soils derived from volcanic rocks, Galapagos Islands (Ecuador). Environ. Geol. 56:45-58.

Alpert, A. 1963. The climate of the Galápagos Islands. Pages 21-44 in Galápagos Islands: A unique area for scientific investigations. Occas. Pap. Calif. Acad. Sci. 44.

Banfield, A. F., C. H. Behre Jr., and D. St. Clair. 1956. Geology of Isabela (Albemarle) Island, Archipiélago de Colón (Galapagos). Geol. Soc. Am. Bull. 67:215-234.

Bow, C. S. 1979. The geology and petrogenesis of lavas of Floreana and Santa Cruz Islands: Galápagos Archipelago, Ecuador. Ph.D. diss., University of Oregon, Eugene.

Bowman, R. 1963. Evolutionary patterns in Darwin finches. Pages 107-140 in Galápagos Islands. A unique area for scientific investigations. Occas. Pap. Calif. Acad. Sci. 44.

Colinvaux, P. 1972. Climate and the Galapagos Islands. Nature (Lond.) 240:17-20.

Dall, W. H., and W. H. Ochsner. 1928. Tertiary and Pleistocene Mollusca from the Galapagos Islands. Proc. Calif. Acad. Sci., 4th ser. 17:89-139.

De Paepe, P. 1968. Bijdrage tot de kennis van de petrologie en van de petrografie van de Galápagos-eilanden. Ph.D. diss., State University of Ghent. 2 vol.

De Paepe, P., and G. Stoops. 1969. Some trace elements in basaltic rocks from the Galapagos Islands. Meded. K. Acad. Overz. Wet. 1969 (2): 365-379. 
Eswaran, H., G. Stoops, and P. De Paepe. 1973. A contribution to the study of soil formation on Isla Santa Cruz, Galapagos. Pedologie 23:100-122.

Franz, H. 1980. Old soils and land surfaces on the Galápagos Islands. GeoJournal 4:182-184.

Geist, D., K. Harpp, and N. d'Ozouville. 2011. Field trip guide. AGU Chapman Conference on The Galápagos as a Laboratory for the Earth Sciences (Puerto Ayora, Galápagos, Ecuador, 25-30 July 2011).

Grant, P. R. 1981. Population fluctuations, tree rings and climate. Not. Galapagos $33: 12-16$.

Gromme, S., E. A. Mankinen, and M. Prevot. 2010. Time-averaged paleomagnetic field at the equator: Complete data and results from the Galapagos Islands, Ecuador. Geochem. Geophys. Geosys. 11. doi:10.1029/2010GC003090.

Hamann, O. 1981. Plant communities of the Galápagos Islands. Dan. Bot. Ark. 34, Bd. 2.

Houvenaghel, G. 1973. Contribution à l'étude de l'écologie marine des Iles Galapagos. K. Acad. Overz. Wet. 19 (1).

Kastendalen, A. 1982. Changes in the biology of Santa Cruz Island between 1935 and 1965. Not. Galapagos 35:7-12.

Laruelle, J. 1963. Exploration géopédologique de l'île Santa Cruz. Not. Galapagos 1:11-13.

- 1966. Study of a soil sequence on Idefatigable Island. Pages 87-92 in R. I. Bowman, ed. The Galápagos. Proc. Symp. Galápagos Int. Sci. Proj., U.C.P., Berkeley.

—. 1967. Galápagos. Natuurwet. Tijdschr. 47 (1965).

Laruelle, J., and G. Stoops. 1967. Minor elements in Galapagos soils. Pedologie 17:232-258.

McBirney, A., and Ken-ichiro Aoki. 1966. Petrology of the Galápagos Islands. Pages 71-77 in R. I. Bowman, ed. The Galápagos. Proc. Symp. Galápagos Int. Sci. Proj., U.C.P., Berkeley.

Morrás, H. J. M. 1974. La alteración y transformación de minerales primários en un perfile de suelo de la Isla Santa Cruz, Islas Galápagos (Ecuador). Rev. Asoc. Cienc. Nat. Litoral 5:15-28.
1975. Algunas caracteristicas geneticas de los suelos de la zona arida de la Isla Santa Fé, Galápagos (Ecuador). Rev. Asoc. Cienc. Nat. Litoral 6:43-48.

-1 1976. Gibbsite glaebules of a soil profile from Santa Cruz Island, Galápagos (Ecuador). Pedologie 26:91-96.

- 1977. Analisis micromorphologico de dos perfiles de suelo de la zona árida de la Isla Santa Fé, Galápagos, Ecuador. Turrialba 27:93-98.

- 1978. Phosphatic nodules from a soil profile of Santa Fé Island, Galápagos. Pages 1007-1018 in M. Delgado, ed. Soil micromorphology. University of Granada, Spain.

Rodriguez Flores, R., C. Ferro Vazquez, G. Stoops, and A. Martinez Cortizas. 2006. Elemental composition of soils developed on volcanic materials of Isla Santa Cruz (Galapagos Islands). EGU-General Assembly, Vienna. Abstract EGU06-A04834.

Sabau, J. 2008. Unexplored territory in the Galapagos Islands. Pac. Reg. Soc. Soil Sci. Newsl. 56:8-9 (www.prsss.ca/pdf/ Newsletters/Newsletter56).

Sachs, J. P., and N. Ladd. 2010. Climate and oceanography of the Galápagos in the 21th century: Expected changes and research needs. Galapagos Res. 67:50-54.

Sedov, S., G. Stoops, and S. Shoba. 2010. Regoliths and soils on volcanic ash. Pages 275-303 in G. Stoops, V. Marcelino, and F. Mees, eds. Interpretation of micromorphological features of soils and regoliths. Elsevier, Amsterdam.

Simkin, T. 1984. Geology of Galapagos. Biol. J. Linn. Soc. 21:61-75.

Steinitz Kannan, M., M. Riedinger, W. Last, M. Brenner, and M. Miller. 1988. Un registro de 6000 años de manifestaciones intensas del fenómeno de El Niño en sedimentos de lagunas de las islas Galápagos. Bull. Inst. Fr. Etud. Andines 27:581-592.

Stewart, A. 1911. A botanical survey of the Galápagos Islands. Proc. Calif. Acad. Sci., 4th ser., 1:7-288.

Stoops, G. 1972. Micromorphology of some important soils of Isla Santa Cruz (Galapagos). Pages 407-420 in S. Kowalinski and J. 
Drozd, eds. Soil micromorphology. Panstwowe Wydawnicto Naukowe, Warsaw, Poland.

2003. Guidelines for analysis and description of soil and regolith thin sections. Soil Science Society of America, Madison, Wisconsin.

- 2007. Micromorphology of soils derived from volcanic ash in Europe: A review and synthesis. Eur. J. Soil Sci. 58:356-377.

- 2013. A micromorphological evaluation of pedogenesis on Isla Santa Cruz (Galápagos). Span. J. Soil Sci. 3:14-37.

Stoops, G., and P. De Paepe. (in press). Vijftig jaar geleden: Een Belgische geopedologische zending naar de Galápagos eilanden (mei-oktober 1962). Meded. K. Acad. Overz. Wet. www.kaowarsom.be/ documents/57-58 (2011-2012/Stoops. pdf).

Stoops, G., and C. E. G. R. Schaefer. 2010. Pedoplasmation: Formation of soil material. Pages 69-79 in G. Stoops, V. Marcelino, and F. Mees, eds. Interpretation of micromorphological features of soils and regoliths. Elsevier, Amsterdam.
Trueman, M., and N. d'Ozouville. 2010. Characterizing the Galápagos terrestrial climate in the face of global climate change. Galápagos Res. 67:26-37.

U.S. Department of Agriculture. 1960. Soil classification: A comprehensive system. 7th Approximation. Madison, Wisconsin.

. 1967. Soil taxonomy: A basic system of soil classification for making and interpreting soil surveys. U.S. Dep. Agric. Agric. Handb. 436.

Walle, P. 1911. Les îles Galapagos et le canal Panama. Bull. Soc. Géogr. Paris 33:594604.

Wiggins, I. L., and D. M. Porter. 1971. Flora of the Galapagos Islands. Stanford University Press, Stanford, California.

Williams, H. 1966. Geology of the Galápagos Islands. Pages 65-70 in R. I. Bowman, ed. The Galápagos. Proc. Symp. Galápagos Int. Sci. Proj., U.C.P., Berkeley.

Wolf, T. 1895a. The Galapagos Islands. Geogr. J. 6:560-564.

- 1895b. Die Galapagos Inseln. Verh. Ges. Erdk. Berl. 22:246-265. 
